\title{
Strategies for Quoting the Holy Scriptures in the Old Polish Biblical-Apocryphal Narrations
}

\author{
Dorota Rojszczak-Robińska \\ Professor, Uniwersytet im. Adama Mickiewicza w Poznaniu, Wydział \\ Filologii Polskiej i Klasycznej, Poznań, Poland \\ dorroj@amu.edu.pl
}

\begin{abstract}
The Old-Polish Biblical-apocryphal narrations are the most extensive manuscripts preserved in the Polish language, the texts very important from the perspective of the beginnings of the Polish literary language. Majority of them have been preserved as copies, quite often copies obtained from other copies. They are based on many different Latin sources, originating from various periods. We can see the creation of a new text from fragments translated into Polish, sometimes quoted, sometimes paraphrased, often combined at the lowest level - within a single sentence. In the paper, I will show how the quotations from The Bible function in those multi-layered and multi-styled medieval texts stemming from many sources.
\end{abstract}

\section{Keywords}

Apocrypha - quoting - Bible - strategies - Old-Polish - medieval literature

\section{Introduction $^{1}$}

The medieval writings in Polish, in comparision with other national literatures, are scarce. The history of Polish literature starts in the 13th century (Bogurodzica [Theotokos] originates from this period), Kazania świętokrzyskie [The Holy

1 Research conducted as part of the grant of the National Science Centre; project no 2017/26/E/ HS2/oooo83: The Beginnings of the Polish Language and Religious Culture in the Light of Medieval Apocrypha of the New Testament. Universal Tool for the Study of Polish Apocryphal Texts, under the leadership of Dorota Rojszczak-Robińska. 
Cross Sermons] and Psatterz Floriański [The Florian Psalter] originate from the 14th century. The majority of the preserved texts stems from the 15th century, and some of them have survived only in copies from later periods. Among the Old-Polish written texts there is not a single complete translation of the Bible. Only two complete psalters have been preserved (the so-called Psatterz Floriański and Psatterz Putawski), we also have - not completely preserved until modern times - Biblia Krolowej Zofii [The Bible of Queen Sophia] (today only two pages with the translation of the Old Testament remain), fragments of Harmonia ewangelii [The Harmony of Gospels] (7 pages of the manuscript containing the excerpts of translations of three Gospels). Some fragments of translations of the Gospels have also been preserved in the Old-Polish apocrypha. ${ }^{2}$ When I say the "Old-Polish apocrypha", I mean the Old Polish Biblical-Apocryphal Narrations, that is texts about the Bible, complementing, commenting and explaining the text of the Scriptures, in other national literatures known as religious romance, Erbauungsliteratur or Christian devotional literature. These

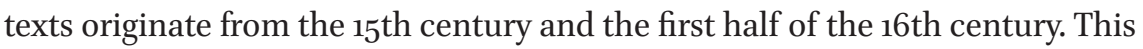
is the largest group of Polish medieval texts that have been preserved (more than 2000 leaves of manuscripts and old prints in total). Until today remained only 9 apocrypha of the New Testament. Seven of them have been kept in manuscript, namely, Rozmyślanie przemyskie (Przemysl Meditation; abbreviated to - RP), ${ }^{3}$ Sprawa chędoga o męce Pana Chrystusowej (Comely Discours about the Passion of Lord Christ; abbreviated to - sch), ${ }_{4}^{4}$ Rozmyślania dominikańskie (Dominican Meditations; abbreviated to - RD), ${ }^{5}$ Karta Rogawskiego (abbreviated to - KR), ${ }^{6}$ List Lentulusa (Letter of Lentulus; abbreviated to - LL), ${ }^{7}$ Ewangelia

2 See T. Michałowska, Średniowiecze, Warszawa, 1996; T. Witczak, Literatura średniowiecza, Warszawa, 1999.

3 Rozmyślanie przemyskie, abbreviated to RP, the manuscript preserved today in the National Library in Warsaw (call number 8024 III). This is a paper codex, encompassing $85^{2}$ pages.

4 Sprawa chędoga o męce Pana Chrystusowej, abbreviated to sch, the manuscript kept in the National Library - call number 3040 IV, copied in 1544 by Wawrzyniec of Łask. It is inserted in a paper codex along with two other texts in Polish (Ewangelia Nikodema and Historyja Trzech Kroli).

5 Rozmyślania dominikańskie, abbreviated to $\mathrm{RD}$, parchment codex containing 122 pages, richly illuminated, nowadays deposited in the Library of the Convent of Barefoot Carmelite Nuns in Cracow (call number 287).

6 Karta Rogawskiego, abbreviated to KR, a parchment leaf, which is kept today in the department of manuscripts of the Princes Czartoryski Library in Cracow in a file with the assigned call number 2566 .

7 List Lentulusa, abbreviated to LL, the manuscript in the Jagiellonian Library, call number 2151, written around mid-15th century, on f. 302v-303r. 
Nikodema (Gospel of Nicodemus; abbreviated to - EN $)^{8}$ and Historyja Trzech Kroli (Story of the Three Kings; abbreviated to - HTK), ${ }^{9}$ and two are preserved in old prints, i.e., Żywot Pana Jezu Krysta by Balthasar Opec (Life of Lord Jesus Christ; abbreviated to - ŻिJK) ${ }^{10}$ and Żywot świętej Anny (Life of Saint Anne; abbreviated to - żsA). ${ }^{11}$

What does distinguish this group of texts? The discussed texts are stories about the life of Jesus and Holy Mary, in Polish studies customarily called the apocrypha, ${ }^{12}$ Biblical-apocryphal narrations ${ }^{13}$ and religious romances. ${ }^{14}$ Among the texts preserved, there are "biographies" of Jesus and Holy Mary, relating the complete stories (RP, ŻPJK, probably - KR) or just fragments of them - the Passion (sch, RD), the story of the travel of the three Magi (нтк) and the life of Saint Anne (żsa).

They are multilayered texts. Firstly, they are multilayered genetically. The majority of these texts are anonymous and survived only as copies. In Polish medieval studies a simplified way of thinking became prevalent: the author of an apocrypha was merely a compiler of earlier Polish translations, whereas a copyist was the one who unintentionally corrupted a text when rewriting it. The most recent studies show that it was different. An author is a compiler but also a translator, a creator, who makes choices and combines, adds his own fragments and removes other. At the same time, a copyist is also a mutator who consciously alters and supplements a text. Moreover, a copyist also corrects the errors left by the first author and adds further comments or explications, or simply - creates successive layers of a text. ${ }^{15}$

8 Ewangelia Nikodema, abbreviated to EN, see note 4.

$9 \quad$ Historyja Trzech Kroli, abbreviated to нтк, see note 4.

10 Balthasar Opec, Żywot wszechmocnego Syna Bożego Pana Jezu Krysta, abbreviated to żPJK, a print from 1522, Hieronim Wietor, a copy from the Library of the Metropolitan Seminary of Warsaw Archdiocese, call number O. 24.1 (74118).

11 Żywot świętej Anny, abbreviated to żsA, a unique copy of the second edition is stored in the Jagiellonian Library, call number Cim. 147.

12 A. Brückner, Apokryfy średniowieczne, Kraków, 1900.

13 M. Adamczyk, Biblijno-apokryficzne narracje w literaturze staropolskiej do końca XVI wieku, Poznań, 1980.

14 J. Krzyżanowski, Romans polski wieku XVI, Warszawa, 1962.

15 See T. Mika, "Genetyczna wielowarstwowość i złożoność tekstów staropolskich a ich badania historycznojęzykowe. Rekonesans”, Biuletyn Polskiego Towarzystwa Językoznawczego, 68 (2013), pp. 131-145; T. Mika, "Literacy as a Context of the Medieval Bible translations into Polish", Polonica, 38 (2018), pp. 263-275; D. Rojszczak-Robińska, "Trudne miejsca Rozmyślania przemyskiego. Problem glos", in:Zbliżenie. Literatura-kultura-język - translatoryka, ed. I. Fijałkowska-Janiak, Gdańsk, 2011, pp. 213-22o. 
Secondly - they are different in style. ${ }^{16}$ We are not only dealing with various genres such as: passion sermons ( $\mathrm{SCh}$ ), a meditation (RD), a letter (LL), a narration, a legend or the lives of saints (ŻSA). Within one text fragments of other genres appear, such as a hymn, a sermon, a song, a prayer, an evangelical harmony or a theological treaty. ${ }^{17}$ Additionally, we are dealing with mixing of stylistic varieties - within one segment there occur the elements of religious, colloquial and official style.

Thirdly - they are multilayered as far as sources are concerned. ${ }^{18}$ Apocryphal material is partly original, created by a particular author and partly translated from many various sources, in their different Latin or sometimes Czech versions. The opinion of influential Polish Slavist, Aleksander Brückner, about slavish faithfulness of Polish apocrypha against their Latin sources ${ }^{19}$ was repeated uncritically for more than a century. Their authors were usually considered as stylistically inapt. It was absolutely unjustifiable. Even in the case of the texts apparently originating from one source (such as Historyja barzo cudna o stworzeniu nieba i ziemie, Ewangelia Nikodema or Historyja Trzech Kroli), it is noticeable that translators did not stop after translating one of the texts. For example, Historia Trium Regum by John of Hildesheim, includes the translation of the entire chapters of the Gospel of St. Luke.

With regard to passion apocrypha, the mosaic is composed of many different texts. The texts always used are the Gospels, prophetic writings of the Old Testament, the writings of the Church Fathers, sermons and other apocrypha

$16 \quad$ See Z. Krążyńska, "Warstwy stylistyczne Rozmyślania przemyskiego", in: Język polski historia i wspótczesność, ed. Z. Krążyńska, Z. Zagórski, Poznań, 1995, pp. 45-52; D. Rojszczak-Robińska, "O powiązaniu analizy stylistycznej i źródłoznawczej. Znad Rozmyślania przemyskiego", Slavia Occidentalis, t. 71/1 (2014), pp. 123-144.

See T. Mika, Bóg, Jezus, Maryja w "Rozmyślaniu przemyskim". O nazywaniu osób, Poznań, 2002; D. Rojszczak-Robińska, "Spowiedź Judasza, czyli o nieznanym staropolskim kazaniu ukrytym w tekście apokryfu”, in: Memoriale Domini. Księga pamiątkowa dedykowana księdzu profesorowi Jerzemu Stefańskiemu w 7o. rocznicę urodzin, ed. M. Olczyk, W. Radecki, Gniezno, pp. 529-545.

18 T. Dobrzeniecki, "Łacińskie źródła Rozmyślania przemyskiego", in: Średniowiecze. Studia o kulturze, ed. J. Lewański, Wrocław, 1969, pp. 196-521; R. Mazurkiewicz, "Kilkanaście dalszych uzupełnień do źródeł Rozmyślania przemyskiego", in: Amoenitates vel lepores philologiae, ed. R. Laskowski, R. Mazurkiewicz, Kraków, 2007, pp. 198-201; R. Wójcik, "Tłumacz, wykładacz, kompilator czy autor? Wokół kompozycji Żywota Pana Jezu Krysta Baltazara Opeca i jego stosunku do Meditaciones vite Christi", in: Baltazar Opec, Żywot Pana Jezu Krysta, ed. W. Wydra,R. Wójcik, Poznań, 2014, pp. XXXI-XCII; D. Rojszczak-Robińska, "Łacińskie źródła Rozmyślania przemyskiego. Pytania, problemy, perspektywy", in: Staropolskie Spotkania Językoznawcze, vol. 1, Jak badać teksty staropolskie, ed. T. Mika, D. Rojszczak-Robińska, O. Stramczewska, Poznań, 2015, pp. 135-154.

19 A. Brückner, Literatura religijna w Polsce średniowiecznej, Warszawa, 1903. 
and narrations. In the paper I will focus completely on one source of the OldPolish apocrypha, i.e., the Bible. The objective of the paper is to present a quoting strategy, and more broadly - the use of - the Bible in the Old-Polish apocrypha. I will also ask which choices of authors are typical for the Old-Polish apocrypha as a genre, and which for particular texts.

\section{$2 \quad$ Individual Preferences}

We can observe certain preferences in the texts that are partly dependent on the use of a particular text. For example, the author of Rozmyślanie przemyskie, which, in part, is a theological treaty, most willingly used the Gospel of St. John and the Gospel of St. Matthew, definitely avoided the Gospel of St. Mark. Sprawa chędoga (a passion sermon) makes very little use of the Gospel of St. John, most eagerly using the material of St. Luke and St. Matthew. Rozmyślania dominikańskie (a meditation) mainly draw upon the St. Matthew's and St. Mark's Gospel. This stems from a different purpose of texts - RP may have served as a sermon book, a helpful tool in teaching; sch is a story contained within a framework of a sermon, whereas RD is intended for individual meditation. Rozmyślanie przemyskie draws upon the Gospels which are mostly theological and provide a more complete picture of events, and, moreover, offer a possibility to juxtapose and compare them. Sprawa chędoga employs simpler texts, is more of a narrative, while Rozmyślania dominikańskie is imaginative. Similar differences can be observed in referring to the prophecies of the Old Testament. Polish writers manifested a different approach to the question of translation of the fragments of the Gospel, which included a quotation from the Old Testament. For instance, the author of sch often simply imitated the version presented by the Evangelist. The author of RP frequently changed and quoted directly from the books of the Old Testament, and also made comments, showing that he was acquainted with the complete Bible. There are excerpts where the author of RP almost automatically supplemented Biblical fragments, drawing directly on the source. He may have quoted from memory. Such a change is visible, for instance, in the scene of the Last Supper. St. John wrote: sed ut adimpleatur Scriptura: Qui manducat mecum panem, levabit contra me calcaneum suum (John 13,18) ${ }^{20}$. He quotes The Book of Psalms

20 Quotations from the Bible originate from the edition: Biblia tacińsko-polska, czyli Pismo Święte Starego i Nowego Testamentu. Podtug textu tacińskiego Wulgaty, i przektadu polskiego x. Jakóba Wujka T.J. z komentarzem Menochiusza T.J. przetożonym na język polski. Reprint: Komorów, 1997. 
(Etenim homo pacis meae, in quo speravi, qui edebat panes meos, magnificavit super me supplantationem ( $\mathrm{Ps}(\mathrm{s}) 40,10)$ ). The Latin calcaneum means 'foot, heel', supplantatio means 'deceit, deceitful conduct'. In the discussed fragment, the author of sch quoted a prophecy from the Gospel:

\begin{abstract}
Aby też popełniło sie Pismo, ktoreż o Judaszu w żołtarzu to przepowiedziało, rzekąc: "Biskupstwo jego weźmie jiny". Jindzie mowi Dawid o nim: "Ktory jadt chleb moj nie przeto, aby pospieszał ku dobroci, ale iżby sie taił, podniesie noge swa przeciw mnie, toczu przeradzając mie deptał"21 (sch 25v/2-8).

[That also the Scripture, which spoke of Judas in the Psalter, was foretold, saying: "His office will be taken by another". Elsewhere David says of him: "He that ate my bread, not to hurry to good, but that he should hide, lift his leg against me, that is, betraying me, trampled me]
\end{abstract}

and the writer of RP quotes exactly from the Book of Psalms:

ale by sie napełniło Pismo, jeż przepowiedano o Judaszu we psalmie rzekąc: «Biskupstwo jego weźmie iny», a tamoż dalej mowi: «Jen używat chleba mego, podniost nade mna swa zdradę» (RP 540/1-6)

[but that the Scriptures shall be filled, that which were prophesied about Judas in the psalm, saying, "Let another take his office"; and there further says: "Who used my bread, lifted his betrayal above me"].

Interestingly, the writer quotes in the following commentary the version from the Gospel:

tegodla, jen używa chleba mego nie przeto, by pomogł, ale by tajemnie zawadził, podniesie piętę swoję nad mie, czuż zdradzając mnie będzie deptać (RP 540/6-10)

[therefore whoever uses my bread not to help, but to secretly disturb, will lift his heel above me, that is while cheating on me will tread on me]

Owing to this commentary the author preserved both versions (which will be explained later). Rozmyślanie przemyskie is even called "a small theological

$21 \quad$ All quoted transcripts of Polish apocryphal texts have been prepared by the team working under my supervision and have been made as part of the realized grant (see footnote 1). They are available on the website: apocrypha.amu.edu.pl. The quotations are identified by providing the abbreviation of the title, leaf number and, after a slash, the range of verses. 
library of the Polish Middle Ages" because of its intention to inform about everything what the Bible said about Jesus and Holy Mary.

The length of these "quotations" varies. They may be combined at the level of individual words (what will be demonstrated later in the paper), sentences, or entire chapters or paragraphs.

The degree of faithfulness also varies: from word for word translation to free paraphrasing. The literal translation preserves the Latin sentence order and structures, as shown in the example:

O wy wszyscy, ktorzy chodzicie drogą, <bac>zcie i widzcie, jeśli boleść rowna jako boleść moja (sch 2v/12-14)

[Oh, you all, who are going this road, look attentively and see, if there is any pain like my pain]

$\mathrm{O}$ vos omnes, qui transitis per viam, attendite, et videte, si est dolor sicut dolor meus (Lam 1, 12).

This way of translation is rather rare (see chapter 3.1). Much more common is the adaptation of a Latin text to the Polish linguistic system or a paraphrase. The degree of faithfulness depends on the type of source: the verses from psalms are usually translated faithfully. ${ }^{22}$ Perhaps this results from the fact that the Psalter was a fundamental text. Latin as a second language was taught on the basis of psalms by using first the sound and later the grammar. The Psalter is the text with which the Old-Polish author came into contact as the person who did not speak Latin and who was illiterate, from which he 1) learned Latin; 2) learned to read and write; 3 ) which he knew completely by heart. That's why the manner of translation of the Psalter is different than translations of texts which the author came across as the bilingual and literate person. ${ }^{23}$

In this paper, for me, the strategy means a special way of quoting and using the Biblical writings. The means of introducing quotations into the text is the subject of a separate study. ${ }^{24}$

22 This is the subject of a separate study: "The Book of Psalms as the Source of the Old-Polish Apocrypha".

23 J. Murphy, "The teaching of Latin as a second language in the 12th century", Historiographia Linguistica, vol. 7 1/2 (1980), pp. 159-174; The Place of the Psalms in the Intellectual Culture of the Middle Ages, ed. Nancy Van Deusen, New York, 1999.

24 In preparation. 


\section{1}

\section{Faithfulness}

As I have already mentioned, many quotations are very faithful; they originate from one source, as in the examples below:

...jako pisano jest o nim w psalmie: "Będą synowie jego sieroty, a żona jego wdowa" (sch 9v/15-17)

...as it is written in the psalm: "His sons will be orphans, and his wife a widow"

Fiant filii ejus orphani, et uxor eis vidua (Ps(s) 108,9).

A dobrześ tu rzekł, Piłacie, prawdę, iże na nim nietu winy, bo tem poćwirdzasz słowo Boże przez Dawida proroka rzeczono w personie Bożej: «Ani zgłoba moja, ani grzech moj, Gospodnie» (RP 788/8-13);

[And you said right here, Pilate, the truth, that it is not guilty on him, for this is what you confirm the word of God told by David the prophet in God's person: "Neither my fault nor my sin, o Lord"]

Neque iniquitas mea, neque peccatum meum, Domine (Ps(s) 58,5).

The texts of Polish apocrypha originate from the 15th and 16th centuries. We can notice a certain difference in Polish literary texts from this period. At the turn of these centuries, a word order natural for the Polish language was replaced in religious texts by an inverted word order, the Latin one. Stanisław Rospond, author of Polish historical grammar, noted:

The most common prenominal position of an adjectival and pronominal attribute in the Old-Polish was of Proto-Slavic origin, but under the influence of the Latin word order (Vulgate, everyday prayers) postnominal ( $p a-$ ter noster-Ojcze nasz, deus meus - Bóg mój) this solemn, different from the typical Polish word order stabilized in prose used in psalters and the Bible $e^{25}$ (emphasis by DRR).

In the earliest apocrypha we observe the word order natural for the Polish language, with a pronominal attribute in pre-position, and in later texts - the inverted order, with a pronominal attribute in post-position. A similar phenomenon with regard to the Old-Polish translations of Modlitwa Pańska was observed by Dorota Masłej:

25 S. Rospond, Gramatyka historyczna języka polskiego z ćwiczeniami, Warszawa, 2003, p. 197. 
The first Polish translations follow the word order typical of the Polish language, and only later they imitate the Latin structure, the fact which also evidences the process of formation of the language as a separate entity, but also strongly drawing upon - as far as syntax is concerned - from Latin, being the language of source texts ${ }^{26}$ (underlined by DRR).

Although the author of Rozmyślanie przemyskie or Karta Rogawskiego used much more often the word order natural for the Polish language, while the author of sch used the Latin, there are also texts which were translated faithfully by all - word for word - in spite of their habits. The examples of such texts are the verses from the Book of Psalms, some writings of the prophets (the Book of Isaiah and the Book of Jeremiah), and also fragments of the Gospels also known from the canons of the Holy Mass:

A wziął Krystus chleb i przeżegnał rzekąc: "To jest ciało moje". [...] "Weźmicie a pożywajcie, to jest ciało moje, ktoreż pod wyobrażenim chleba widzicie" (sch 26r/15-26v/1)

[And Christ took the bread and blessed it, saying, "This is my body." [...] "Take and eat, this is my body which you see under the image of bread] Wziąwszy miły Jesus chleb i pożegnał rzekąc: "Toć jest ciało moje”. [...] "Weźmicie a jedzcie. Toć jest ciało moje, ktoreż pod wyobrażenim chleba widzicie" (RP 541/19-542/3)

[Kind Jesus took the bread and blessed it saying, "This is my body." [...] "Take and eat. This is my body which you see under the image of bread] "Podźcie bierz[sz]cie i pożywajcie, toć jest ciało moje, ktore za was będzie wydano tej nocy na mękę" (RD 50/13-17)

["Come, take and eat, this is my body, which will be given up for you tonight"]

Et accepto pane gratias egit, et fregit, et dedit eis, dicens: Hoc est corpus meum, quod pro vobis datur: hoc facite in meam commemorationem (Luke 22,19).

In all three texts the fixed phrase corpus meum was rendered in the same way (ciato moje), instead of order natural for Polish (moje ciato). The text of the canon was well known. Some surviving synodal laws require the examination of priests on their knowledge of the canon. Mariusz Leńczuk, a scholar studying the Old-Polish glosses for the Latin canon of the Holy Mass, ascertained: "In

26 D. Masłej, "Problem szyku w staropolskich przekładach Modlitwy Pańskiej”, Kwartalnik Językoznawczy, 4 (2013), pp. 37-38. 
Poland, in the 15th century one order of the Holy Mass was observed, and consequently, the individual copies of the canon of the Holy Mass in Latin showed no differences". 27

Faithful rendering of the text in the Old-Polish apocrypha is thus a conscious decision, and not an evidence of stylistic incompetence of their authors, as it was thought for many years. This may also be a result of habits, the requirements of knowing specific texts or the methods of education.

\subsection{Reduction}

A different strategy is an intentional reduction. The description of feeding the multitudes in RP ends with the sentence:

Ostawiwszy tu miły Jesus tłuszcze, wsiadszy w łodzią i poszedł od nich (RP 360/9-11)

[Leaving here good Jesus the crowds, he entered the boat and left them].

This is a translation of the Gospel of St. Matthew (Matt 15,39): Et dimissa turba, ascendit in naviculam, et venit in fines Magedan. The author did not translate the information about the destination: in fines Magedan. This kind of a gap (omission) may serve to solve the question of incompatible versions of the Evangelists. In a parallel place of the Gospel of St. Mark a different placename is given: Et statim ascendens navim cum discipulis suis, venit in partes Dalmanutha (Mark 8,10). Magedan, known also as Magdala, and Dalmanuta are the two towns of the ancient Galilee. They are both located at the Lake Tiberias. The Polish author did not make the decision which of them to mention, so he omitted this information.

A similar situation occurs also in another place, in the description of walking on water where the journey's destination is not mentioned too, so as not to decide whether it was Capernaum (in St. John's version) or Bethsaida (in St. Mark's version):

Et cum ascendissent navim, venerunt trans mare in Capharnaum: et tenebrae jam factae erant... (John 6,17).

Et [...] ascendere navim, ut praecederent eum trans fretum ad Bethsaidam (Mark 6,45).

A gdyż są wstąpili w łodzią, tako już mrok padł, iże było ciemno (RP 350/12-14)

[And when they entered the boat, nightfall came so that it was dark].

27 M. Leńczuk, Staropolskie przekazy kanonu Mszy Świętej. Wariantywność leksykalna, Warszawa, 2013, p. 46. 
It is also so in the fragment of so-called missionary speech, which is the translation of verse 35 of chapter 22 of the Gospel of St. Luke:

Et dixit eis: Quando misi vos sine sacculo, et pera et calceamentis: numquid aliquid defuit vobis? At illi dixerunt: Nihil (Luke 22,34-36).

Polish authors translated this fragment in this way:

A potem, obrociwszy sie ku zwolenikom swym i rzekł jim: "Namilszy synowie, gdym was słał ku przepowiadaniu Ewanjelijej przez workow i przez toboły, aza wam czego kiedy niedostało?". A oni rzekli są jemu: "Nic niedostawało nam" (sch 35v/16-36r/3)

[And then, turning to his followers, he said to them: "Pleasurable sons, when I was sending you to preach the Gospel without sacks and without a purse, did you ever lack anything?" And they said to him, "We lacked nothing"]

A miły Jesus począł potym mowić k nim: "Kiedym was słał przez miecha i przez toboły, azali wam czego niedostawało?". A oni rzekli wszycy: “Nic, wszegosmy dosyć mieli" (RP 581/12-18)

[And then kind Jesus started talking to them: "When I was sending you without a sack and without a purse, did you lack anything?" And all of them said, "Nothing, we had enough of everything "]

Zatym miły Jesus począł lepak mowić k niem: "Kiedym was słał przez miecha albo kalety, azali wam czego niedostawało?". A oni rzekli wszytcy: "Nic, wszegosmy dosyć mieli" (ŻPJK6ov/23-26)

[Then kind Jesus again started talking to them: "When I was sending you without a sack and without a purse, what did you lack?” And all of them said, "No, we had everything"].

In his utterance Jesus uses the so-called missionary speech. Each of the Evangelists rendered this kind of speech differently, recording the instructions of Jesus in their own manner. According to St. Mathew, Jesus sent his disciples without sandals (Non peram in via, neque duas tunicas, neque calceamenta, neque virgam Matt 10,10), according to St. Mark - in sandals (Et praecepit eis, ne quid tollerent in via, nisi virgam tantum; non peram, non panem, neque in zona aes, sed calceatos sandaliis, et ne induerentur duabus tunicis Mark 6,8-9). St. Luke does not mention footwear at all (Et ait ad illos: Nihil tuleritis in via, neque virgam, neque peram, neque panem, neque pecuniam, neque duas tunicas 
habeatis Luke 9,3), whereas in another place claims that Jesus sent his disciples without sandals (Nolite portare sacculum, neque peram, neque calceamenta, et neminem per viam salutaveritis Luke 10,4). The three Polish authors omitted this information as it was inconvenient.

With reference to the Old-Polish texts, we seldom speak using the category of "deficiency". The question, what was used, is rarely accompanied by the reflection upon what was omitted. The process of omission demonstrates the awareness of the Old-Polish authors, the creative process and the skill in using sources.

\subsection{Repetitions}

Sometimes, instead of combining two evangelical versions - the situation which will be discussed in a moment - writers simply presented a particular event twice, in two different places of the narration. An example of this is the scene of raising of Jairus' daughter.

O tem, jako miły Jesus uzdrowił dziewkę jednego biskupa żydowskiego Książę jedno żydowskie, na imię Jairus, przyszedwszy ku miłemu Jesukrystu i prosił jego, aby raczył wnić w jego dom a uzdrowił jego dziwkę (RP 295/18-296/3).

[About this, as kind Jesus healed the daughter of one Jewish bishop. One Jewish prince named Jairus came to nice Jesus Christ and asked him to deign to enter his home and heal his daughter].

Czczienie o tem, jako jedno książę żydowskie prosiło Jesukrysta, aby raczył wnić w jego dom i uzdrowić jego dzicię a Jesus szedszy i uzdrowił je z martwych Książę jedno żydowskie przyszło ku Jesusowi. Prosił jego, aby raczył wnić w jego dom a uzdrowić jego dziwkę (RP 221/5-14).

[Reading about it, as one Jewish prince, asked Jesus Christ to deign to enter his home and heal his child, and Jesus went on and healed it from the dead. One Jewish priest came to Jesus. He begged him to deign to enter his home and heal his daughter].

The author recounted the same event twice, once, drawing upon the Gospel, another time, upon non-canonical text. The situation repeats in the description of how a blind man was healed near Jericho. In RP, this miracle occurs once in the selected version of St. Matthew, ${ }^{28}$ and for the second time in the

28 The Gospel of St. Matthew provides an account of this miracle twice, and every time there appear two blind man, see Matt 9, 27-31 and 20, 29-34. 
version of St. Luke enriched with the details drawn from the Gospel of St. Mark. The situation is similar in the description of how the apostles were called.

This aspiration to make use of everything is especially conspicuous in Rozmyślanie przemyskie, although much more often reveals in combining different versions (it will be discussed below). Until now, this kind of treatment was evaluated in the following way: "the repetition of the same, or even contradicting versions of events will still appear in RP several times. This demonstrates that many elements are amassed without special purpose, and used in the writing of an inconsistent text". ${ }^{29}$ In my opinion this accumulation of material is not done without purpose because the writers developed many different ways of coping with apparently contradicting accounts of the Evangelists.

\subsection{Compilation}

Much more common, however, is combining several source texts or adding some elements to the main text. I have already indicated one such place when, instead of the quotation from the psalm in the Gospel, the author "substituted" a fragment directly from the Old Testament. Much more often, such linkage appears in places of diverging versions of the Evangelists, as for instance in this fragment:

Tedy miły Jesus wstąpiw w łodzią, przewiozł sie i przyszedł do swego miasta Kafarneum. A tu jemu ofierowan paraliżem zabity, leżący na łożu. A nieśli ji k niemu czterzej. A gdyż tamo przyszli, nie mogli jego $\mathrm{k}$ niemu przyprawić przed tłuszczami. Tako wlazszy na dach i odbili deszczki, i spuścili łoże $<\mathrm{z}>$ wirzchu, na ktoremże on leżał paraliżem zarażony (RP 292/14-23)

[Then a good Jesus entered the boat, and travelled and came to his city, Cafarneum. And here he was offered a paralytic, lying on the bed. And four carried him to him. And when they came there, they could not get to him because of the crowd. They got up on the roof and took off the boards and dropped the bed on which this paralyzed lay].

Polish writer had compiled this fragment from three Gospels:

Tedy miły Jesus wstąpiw w łodzią, przewiozł sie i przyszedł do swego miasta [Then a good Jesus entered the boat, and traveled and came to his city] - the return by boat described only in the Gospel of St. Matthew;

29 T. Dobrzeniecki, “Łacińskie źródła Rozmyślania przemyskiego", in: Średniowiecze. Studia o kulturze, ed. J. Lewański, Wrocław, 1969, p. 335. 
Kafarneum [Capernaum] - the town name appearing only in St. Mark. A tu jemu ofierowan paraliżem zabity, leżący na łożu [And here he was offered paralyzed, lying on the bed] - used in all Gospels, stylistically after Matthew.

A nieśli ji k niemu czterzej [And four carried him to him] - the number is only mentioned by Mark, Luke says about some people, Matthew uses just they brought.

A gdyż tamo przyszli [And when they came there] - no source - setting of time;

nie mogli jego k niemu przyprawić przed tłuszczami [they could not get to him because of the crowd] - very similar versions by Mark and Luke, no such version by Matthew.

Tako wlazszy na dach [They got up on the roof] - about ascending a roof in Luke

i odbili deszczki [and took off the boards] - about dismantling a roof only in Mark;

i spuścili łoże $<z>$ wirzchu, na ktoremże on leżał paraliżem zarażony [and dropped the bed on which this paralyzed lay] - about lowering a bed after Mark.

It is evident that linking takes place at the level of individual words and expressions. Writers created specific mosaics, sometimes ordering the events in a logical sequence (doing it on their own or applying the solutions by St. Augustin), sometimes combining texts from the smallest fragments.

This is so, for example, with the description of healing of the mother-in-law of Simon Peter. We read:

Uźrąc ją, miły Jesus dotknąt sie jej, rzekąc, a niemoc ta ista natychmiast ją opuściła (RP288/7-9)

[On seeing her sweet Jesus touched her while saying and her infirmity left her immediately].

The Evangelists differed in the way of describing this event: according to St. Mathew (and Mark) healing was done by holding the woman's hand (et tetigit manum ejus et dimisit eam febris, et surrexit, et ministrabat eis (Matt 8, 15)), according to Luke special words had to be pronounced - the injunction: et stans super illam imperavit febri; et dimisit illam (Luke 4, 39). The Old-Polish author knew both versions and did not want to decide on the version - a gesture or a word, as he could render both in Polish. 
Sometimes writers include specific elements from the descriptions of various Biblical events (for instance using the name of the protagonist from a different scene or adding glosses). For example, in the scene of entering Jerusalem in sch we read:

A gdyż przybliżył sie ku Jerusalem i przyszedł do Betfa<g>e na Gorę Oliwetską, posłał dwu uczniu swoju, to jest < Piotra > i Filipa, rzekąc jim: "Jidźcie do grodka, jenże przed wami jest, a natemmieście, wszedwszy, najdziecie oślicę przywiązaną a oślątko z nią na rostaniach. Odwiążcie i przywiedźcie mi ją" (schır/9-15)

[And when they drew near unto Jerusalem and were come to Bethphage unto the mount of Olives, then Jesus sent two of his disciples, i.e. $<$ Peter $>$ and Philip, saying unto them, "Go into the village over against you, and straightway you shall find an ass tied and a colt with her between two ways. Loose her and bring she unto me].

The writer follows here the version of St. Matthew:

Et cum appropinquassent Jerosolymis, et venissent Bethphage ad montem Oliveti, tunc Jesus misit duos discipulos, dicens eis: Ite in castellum, quod contra vos est, et statim invenietis asinam alligatam, et pullum cum ea: solvite, et adducite mihi (Matt 21,1-2).

The two remaining Evangelists provide here other names of towns (according to St. Mark - Betania, according to St. Luke - Betfage and Betania) and indicate only a donkey, adding "super quem nemo adhuc hominum sedit" (Mark 11,2, similarly Luke 19,30). The wording occurring in the Polish text is puzzling: $n a-$ jdziecie oślicę przywiqzana a oślatko z niq na rostaniach [you shall find an ass tied and a colt with her between two ways]. As long as the first part is a literal translation of: asinam alligatam et pullum cum ea (Matt 21,2), na rostaniach seems to originate from the Gospel of St. Mark, from a fragment of text appearing later and telling what the disciples did when they found a donkey. Only St. Mark mentions that they found it at the crossroads: Et abeuntes invenerunt pullum ligatum ante januam foris in bivio (Mark 11,4). Most likely, the author knew the entire text and, possibly, wrote his own from memory.

For example, when describing St. Peter betraying Jesus three times, the author of RP used almost all forms of St. Peter's reply. This led to the situation in which St. Peter was reproached five times, and not three times - according to the Biblical tradition - about his relationship with Jesus. This scene shows great skill of the writer in combining versions and, at the same time, his control 
over the fabular layer. According to RP, St. Peter only three times responds to the allegations, renouncing his master. Symbolism of a three was preserved but, simultaneously, the four versions of Evangelists were combined.

\subsection{Alterations}

The Old-Polish writers of the apocrypha treat the text of the Gospel as a collection on which they can draw freely. And although, with regard to the Gospel, we do not notice significant substantial changes (as it happens, for instance, when the authors utilize Historia scholastica by Petrus Comestor), and a large part of alterations can be explained by combining several versions, for example in the scene of the Last Supper: "Jeden z was mnie ma na śmierć wydać" [One of you shall give me to death] (RD 46/17-18). In the Gospels in this place we read: "unum vestrum me traditurus est" (Matt 26,21). Other Evangelists (i.e., Mark and John) used similar wording. The Latin trado (pol. wydać) meaning 'transfer' (also 'betray') was expressed with the object: wydać na śmierć - "give to death". What is noticeable in all Polish texts, is the intention to blame Judas for all suffering of Jesus which is revealed in very literal descriptions of his deeds.

Sometimes the alterations, those more important ones, result from quoting the Gospel on the basis of some other source. Polish authors usually correct the errors of the source text when it is for example the 13th-century treaty Vita rhythmica or Historia scholastica. It is different with the writings of St. Augustin - here they adopt the entire text faithfully, without analysis. The result is, for instance, the following:

K temu odpowieda święty Augustyn w "Księgach o zjednaniu ewanjelist", iże święty Jan wypisał niektore rzeczy i [...] wraca sie k swemu powiedaniu rzekąc: "Przywiedli sa Jesukrysta do Kajfasza w wietnicę", czuż słudzy od Annasza, składnika i towarzysza, i świokra Kajfaszowego (RP 7O2/2O703/24)

[Saint Augustine responds in the Books on the harmony of the Gospels, that Saint John wrote some things, he returns to his speaking, saying: They brought Jesus from Caiaphas to the town hall, that is, the servants of Annas, the companion and father-in-law of Caiaphas]

[Ioannes] Redit enim ad locum narrationis suae [...] atque inde regressus [...]: Adducunt ergo Iesum, inquit, ad Caipham in praetorium. Ad Caipham quippe ab Anna collega et socero eius dixerat missum (Augustin, In Ioannes Evangelium... 114.1).

Adducunt ergo Jesum a Caipha in praetorium (John 18,28). 
In the quoted fragment of the Gospel of St. John, the preposition od (Latin $a-a$ Caipha) was changed for do (Latin ad-ad Caipham). The writer claims that he referred to the De consensu Evangelistarum of St. Augustin. However, the source of this fragment is the treaty 114 from The Treaties on the Gospel of St. John by St. Augustin.

It may be an error of a copyist who rewrote this fragment committing mistakes. It is more likely, however, that the author of RP quoted directly from St. Augustin, and quoted this fragment of the Gospel with a mistake, a mistake which was made by the Apostolic Father: Adducunt ergo Iesum, inquit, ad Caipham in praetorium. Despite the fact that the writer of Rozmyślanie must have known the Bible perfectly, he did not correct his favorite Father of the Church.

\subsection{Additions}

A characteristic feature of the Old-Polish apocrypha is a vast commentary on Biblical texts. Quite frequently, these comments stem from other sources, e.g., the writings of Church Fathers, like here below:

...gdyż dyjabeł z osobnego poduszczenia już wpuścił w serce - nie wierząc, iż by Bog był - iżby ji zdradził Judasz (RP531/2-5)

[because the devil has already let him into his heart from a separate suggestion - not believing that he would be God - that Judas would betray him]

cum diabolus jam misisset in cor, ut traderet eum Judas Simonis Iscariotae (John 13,2)

...spiritalis suggestio est... (Augustinus, In Ioannis Evagelium tractatus centum viginti quatuor, 55.4 )

non credens esse Deum (gl).

A przyszedszy do Piłata nie weszli w witnicę, czuż w tę część domu, ktorą Piłat dzierżał, [...] aby sie nie pokalili, iże były dni wielikonocne, kiedy mieli używać baranka wielikonocnego $k$ wieczoru... (RP 748/3-12)

[And those who came to Pilate did not enter the praetorium, that is, in the part of the house which Pilate managed [...] so that they would not scale, because there were Passover days in which they were to eat the Passover lamb in the evening]

Et ipsi non introierunt in praetorium, ut non contaminarentur, sed ut manducarent Pascha. (John 18, 28)

...hoc est in eam partem domus quam Pilatus tenebat (Augustinus, In Ioannis Evangelium tractatus centum viginti quatuor, 114.2). 
Some of the comments are a kind of recommendations given by sermonists. The authors of apocrypha draw upon the text of the Bible in order to propose to the readers/listeners real solutions. The aim of such comments is not only to explain but also to educate:

Tedy rzekł jim: "A przez to dajcie, co jest cesarzewo, cesarzewi, a co jest Boże, Bogu” (jakoż są pierworody, dziesięciny i jine obiaty) (schi7r/12-15) [Then said he unto them: Render therefore unto Caesar the things which are Caesar's and unto God the things that are God's, such as first harvest, tithes, other offerings]

Tunc ait illis: Reddite ergo, quae sunt Caesaris, Caesari et, quae sunt Dei, Deo (Matt 22,21).

In the translation of the St. Matthew's Gospel a recommendation was included - jakoż sa pierworody, dziesięciny i jine obiaty. It was commented similarly in the Polish Middle Ages, as for example in the manuscript of the Capitular Library in Wrocław call number 43. The gloss to this Latin fragment of the Gospel is: vero primicias prazma pirzwe żyto (GlWroc95r) ${ }^{30}$, which means 'the first harvest'. In the 16th century, this was explained in a similar way by Jesuit, Jakub Wujek: "Cesarzowi czynsz i pobór, a Bogu dziesięciny i ofiary" [Rent and collection to the emperor, and tithe and offerings to God].

This layer of commentary in the Old-Polish apocrypha comes from many sources - some of them originated from the Bible (as discussed above), some from other Latin sources, as Historia scholastica by Petrus Comestor or the treaties of St. Augustine, while some sources have never been indicated. There are numerous excerpts in which the comments demonstrate the author's knowledge and evidence his attention to the recipient - also a common person, not necessarily a learned theologian. It can be concluded that the audience of the Old-Polish apocrypha are, on the one hand, people with simple mentality and little knowledge, on the other hand - people who are supposed to instruct others.

\section{Awareness}

There is one more question about the awareness of the Old-Polish writers. It is my impression that they make use of the Bible intuitively and rarely directly

30 Quoted after the website of the project: "The Old-Polish translations of the New Testament": www.stnt.ijp.pan.pl. 
reveal their source, most often with the formula: "Jako mowi święty Jan" [As Saint John speaks], "Podług świętego Macieja" [According to St. Matthew] or "jak sie czcie w Tobijaszu" [As we read in Tobias]. Occasionally, there are mistakes in indicating the source - as in the fragment that was discussed before where the wrong book by Augustine was referred to. We have the same situation in the fragment below:

A mogł jemu rzec miły Krystus ono słowo, ktore pisze święty Maciej rzekąc: "Nie miałby mocy nijednej przeciw mnie, by-ć nie była dana od wyższej mocy" (RP 846/14-19)

[And Jesus could have told him these words, which St. Matthew writes, saying: You would have no power over me if it was not given to you from above]

Respondit Jesus: Non haberes potestatem adversum me ullam, nisi tibi datum esset desuper (John 19,11).

The quotation from the Gospel of St. John was announced as originating from St. Mathew. Such mistakes, in case of sentences, or sometimes even complete passages, are quoted accurately but they are attributed incorrectly, may attest to the fact that these fragments were quoted from memory. This may also stem from a typically medieval attitude to the teaching of the Church as a complete system.

\section{5}

\section{Conclusions}

In the Polish Middle Ages we come across (as in other medieval vernacular languages) two types of translations of the Bible: exact, called literal, intended to "satisfy the needs of private religiousness [...] faithful, without glosses and comments", and also free, called idiomatic, "with numerous glosses and annotations; unrestricted word order, the style resembling colloquial speech".31 Irena Kwilecka, a researcher of old translations of the Holy Bible, points out that the apocrypha (she mentions RP and żPJK) are of the second type, dynamic equivalence or even paraphrase. Essentially, one must agree with this assertion. However, the Old-Polish writers, depending on the situation, practise both kinds of translations. They can translate faithfully, especially the Books of the Prophets, and the language of such translations can hardly be called colloquial. They provided foundation for the Polish Biblical style.

$31 \quad$ I. Kwilecka, Studia nad staropolskimi przektadami Biblii, Poznań, 2003, pp. 128-129. 
It must be noted that the Old-Polish authors developed several strategies of quoting/utilizing and translating Biblical verses. The manner of quoting depends, among other things, on the use of a text. In RP, which is considered as a theological treaty, we can see a preponderance to link different versions of the Evangelists. The author of RP did this in a natural way. The authors of Rozmyślania dominikańskie, which is a book of meditations, or Sprawa chędoga, i.e., an extended passion sermon, much more often draw on one Gospel (most often on the Gospel of one of the Synoptics).

Of course, we must remember that at that time many copies of particular books of the Holy Scriptures were in circulation, in many various editions. We do not know exactly what sources were used by Polish authors. Comparative studies demonstrated that they did not utilize the same editions.

Also, the type of source influences the quoting manner. It is conspicuous that, for example, the fragments of psalms and also some prophecies from the Book of Isaiah and Jeremiah are quoted more precisely. The Gospels are treated as a collection, very often supplemented with the comments of the Fathers of the Church or, typically, with apocryphal insertions.

The strategy of quoting used most often is compilation, alteration and commentary. Less popular is repetition, faithfulness and intended omission.

All of the above findings lead to one general conclusion: the Old-Polish apocrypha are written by distinct authors. They are not just a compilation of translations of several Latin texts. Ernst Curtius expressed his opinion about the writings of Isidore of Seville:

If we call his writings a compilation, then we should know that this discrediting characterization is out of place in this case. Compilation is a literary genre that was greatly popular and appreciated in the period of late Antiquity. ${ }^{32}$

The term compilation had been used for many years in order to negatively evaluate these Old-Polish works. Maria Adamczyk, who forged the term "Old-Polish Biblical-Apocryphal Narrations", contended that Rozmyślanie przemyskie was a "typical compilation, composed of the borrowed, very different and translated in subsequent readings expressions". ${ }^{33}$ Also Roman Mazurkiewicz asserted: "the Old-Polish apocryphal works are almost entirely translations,

32 E.R. Curtius, Literatura europejska i tacińskie średniowiecze, transl. A. Borowski, Kraków, 2009, p. 472.

33 M. Adamczyk, Biblijno-apokryficzne narracje w literaturze staropolskiej do końca XVI wieku, Poznań, 1980, p. 129. 
alterations and compilations of Latin sources". ${ }^{34}$ The authors of the Old-Polish apocrypha were called "assemblers", "compilers". Nowadays, we have found that they combined the material consciously, leaving their individual mark which led to the creation of a new written work. Brenann Breed argued that the original text is just a representation and that every change creates a new work. ${ }^{35}$ The medieval authors of the apocrypha made use of the texts of other writers, including the text of the Bible, creating a new valuable quality.

34 R. Mazurkiewicz, Staropolskie apokryfy, on-line: <http://www.staropolska.pl/srednio wiecze/biblia_i_apokryfy/apokryfy.html> [15.o9.2019].

35 See B. W. Breed, Nomadic Text. A Theory of Biblical Reception History, Indiana, 2014. 